\title{
Describing a Smart Learner in Mastering the English Speaking via Text Message Interview
}

\author{
Imam Dui Agusalim \\ Politeknik Elektronika Negeri Surabaya, Jln. Raya ITS, Keputih, Sukolilo, Surabaya, Indonesia
}

\begin{abstract}
In a country of which English is considered as a foreign language, learners are lack of practicing in using the English language for real communication in their life. They prefer talking in their own languages. Their environment does not support them to have the emersion situation. The books they use are not printed in English. Their teachers do not use English for explaining their subjects. They never get a speaking test in their learning test. So they are not fluent in speaking the language. As the result they are not confident in communication. In the contrary, the problems are answered by a qualified student. How does the smart student becomes fluent in non English speaking country is explored in this research. It presents about the way how to be good a English speaker. She is interviewed via text-message interview to answer some questions about the activities how she becomes a good and fluent in Speaking English. As a part of qualitative research, her answers are used as the data that are employed to describe the activities that support her as a qualified English speaker. The findings are concluded that she becomes fluent in speaking because she makes herself as an english user in various activities.
\end{abstract}

Keywords: English Users, Text-message, Native Speakers, Interview and Assignment.

DOI: $10.7176 / \mathrm{JEP} / 11-30-06$

Publication date:October $31^{\text {st }} 2020$

\section{Introduction}

There are a lot of students around the globe that are still hard to speak English fluently. With the unlimited learning alternatives in the modern era, the question is not what kind of training to choose. The question is how to use the language a lot. How to adopt a regular practice to make the most of effective usage that's learned. That's how to become completely English users in immersive condition. Nunes said: "Want to become fluent in English? Immersive traveling is the most effective way. Start your amazing journey now. Without leaving your home" (Linguagile.com) In the process, how the smart students have developed their own approach to becoming fully fluent in foreign tongues may be useful for the students. Mikhail Kotykhov (2020) stated that "English is not a science. It's a skill. Don't study it. Use it." (quora.com. Retrieved on September 1, 2020). One cannot speak English when he just study the language without using it. He admited that he was studying the English language for more than 15 years without much progress. After that he learned how to speak it, himself, in less than a year. He managed to the language completely by himself. There was no You Tube or other online speaking/listening resources at that time. From the description above, it is clear that in order to be fluent in English speaking, someone must immerse himself in foreign language and become the user of the language.

\section{Problems of Research}

Why a student can speak English well becomes the focus of discussion in this study. The answer to this problems are only related to the activities how a student becomes an English user. The more the student uses it, the better language she has in oral communication. The question is how often the student uses the English language in their daily activity. What are the activities that support her to be fluent in speaking?

\section{Research Procedures}

This study plans to get the portrait of a smart student who becomes fluent in speaking English. The data are collected by making an interview about her ways of being English users. The steps of getting the data are as follows: First, as a part of speaking lesson, the teacher teaches the students about the way how to make an English presentation. In this lesson, the teacher knows his student who is smart in speaking or not. When he has already known who the best speaker in the class is, he can make an interview about her way how to be an english speaker via text messages. So the presence of the researcher is a crucial factor; in this case the research has the role of key instrument. He collects data through an online interview. In-depth interviews, as described by Yuen (2005: 18) formed the main source of data gathering. This interview provides the desciption about her experience in using the language activities that are actually the answer of a qualitative research.

\section{Review of Literature}

Louma (2004) states that Communication-oriented tasks focus on examinees' skills to structure information effectively and communicate smoothly in a socially acceptable manner. These have been used in speaking tests for a long time, but communication-oriented criteria are quite new. To create them, assessment developers need to 
observe learner performances on the tasks and specify what it is that makes them more or less successful from the perspective of reaching the task goals. In information-related talk such as narratives or explanations, success partly depends on the content and sequencing of the examinees' talk. Another part has to do with how the examinees deliver the information: how fluent and accurate they are, what strategies they use to keep the interaction going and get their message across, and how well they take the listener into account.

The collected assignments, which are in the form of perfect paragraphs describing their experiences in mastering English language, are submitted to the teacher and used as the way how to organize the data of this research. Another way that is also done to collect the data is by texting the smart students. They are asked to described their experiences in mastering the Speaking Skills. Finally, all data are interpreted to answer the problems of research.

\section{Analysing the data collections}

The researcher collected the text data by means of an online interview, and documentary study in the form of student assignment. The text data for the study are obtained by employing multiple data collection methods including interview and documentary sources (Spradley, 1980). The interviews involved outlining a set of issues to explore the subject's series of experiences from childhood up to the period of being a university student. By analysing the information given by the smart student who has been fluent and good in pronunciation, it is helpful to think about the activities which have already been done. Take a look at the following data:

Hi Felic, this is Mr. imam Dui, your former English

lecturer. can you tell me about the way you master the

English Language? 7:08 PM $\checkmark$

Sorry if it disturbs you, but I need your information.

:09 PM

Please write it when you are free.

\section{$7: 12 \mathrm{PM} W$}

Hallo Mr Imam. To be honest I am not expert. I had my

first english course in LIA when I was in elementary school.

and my senior high school gave so many opportunities

My school provides native speaker so we can practice

with them once a week

yes sir

The description shows that she has begun to study the English language since she was in elementary school. She has joined a well-known English course called LIA, an agent for Indonesia-America relationship. She was lucky to get her senior high school that provides her with native speakers. It is quite rare to get a native speaker in Senior High School due the high expense of accomodation. She admited that she could practice with the native speaker once a week. The regular practice of being English user with the native speaker makes her fluency and pronunciation really good in oral communication. Bisedes, her senior high school students also gave her many opportunities in using the language, though how they contributed to her language improvement is not described.

Based on this description on each of the subjects, the researcher has found the student has come up with a successful improvement in mastering the English language. The researcher then makes his own conclusion after synthesizing her series of activities of being English user. Her successful improvement is a long-term process and step by step activities in using the English language. The success of the student in mastering the language here is in line with Borg (2006:32) who states that the process of professionalism is described as a long-term process that includes regular opportunities and experiences planes systematically to promote growth and development in the profession. From the findings obtained regarding the successful subject, the researcher can then see that her process can be synthesized into two common themes, her autonomy and lifelong learning education. 
What about the activities that improve your vocabulary?

and my school also has listening class with the audio room so we can practice the listening task from british council

You

What about the activities that improve your vocabulary?

I watched movies with english subtitle

Did you also read novels?

You

Did you also read novels?

just articles sir

7:17 PM

Do you often make English chat? 7:18 PM $W$

How did you get the articles?

7:19 PM

You

Do you often make English chat?

just daily conversation with my friends, and its mix between bahasa and englis

Did you go abroad often?

You
How did you get the articles?
I usually found the articles when I need some
information about college stuff
or read political news 7:21 PM
or royal family history because I like it 7:21 PM
You
Did you go abroad often?
no sir

\section{Conclusion}

Learning about the experience of a smart student in mastering the English language may help other students learn more. This expanding cycle of knowledge helps other learners develop better language competence and the moves how to be English users can be concluded as follows: 
1. The learner has begun to use the English language since she was in Elementary school.

2. She joined a qualified English course which immerses her in using the language.

3. The school provided her native speakers who gave her opportunity to use the language more often.

4. Her senior students gave her more chances to use the listening fasilities of the English language.

5. She often uses a mixed language for communication with her friends. This means that she refreshes her vocabulary.

6. Her interest in reading articles about royal family, political news makes her active in using the language.

7. Movies with english subtitles gives her more fun time to involve with the english language.

The subject is successful in mastering the English language because she has been active immersing herself in using the language via various language activities in her long life.

\section{References}

Borg, S. 2006. Teacher Cognition and Language Education: Research and Practice. London: Continuum International Publishing Group.

Creswell, John W. 2003. Research Design: Qualitative, quantitative, and mixed method approaches. United States of America: Sage Publications, Inc.

Louma, Sari. 2004. Assessing Speaking. Cambridge: Cambridge University Press.

Kotykhov, Mikhail. 2020. "English is not a science. It's a skill. Don't study it. Use it." (quora.com. Retrieved on September 1, 2020).

Spradley, J.P. 1980. Participant Observation. New York:Holt, Rinehart and Winston.

Yuen, F.T. 2005. Subject-Matter Knowledge and Teachers' Planning and Teaching:An Interpretive Qualitative Study of Western Australian TESOL Teachers within the ELICOS Setting. Unpublished dissertation: Graduate Program in English Language Education, University of Western Australia. 